\title{
Economic productivity and competitiveness of Ukrainian exports due to the global challenges
}

\author{
Lesia Petkova ${ }^{1, *}$, Olena Berezina ${ }^{1, * *}$, Iryna Honcharenko ${ }^{1, * * *}$, and Ihor Osadchenko ${ }^{1, * * * *}$ \\ ${ }^{1}$ Cherkasy State Technological University, 460 Schevchenko Blvd., Cherkasy, 18006, Ukraine
}

\begin{abstract}
Productivity and economic growth are key factors to maintain and improve the competitiveness of nations in the global market. The paper analyzes the prospects for the competitiveness of Ukrainian exports in the terms of pandemic circumstances and post-pandemic recovery of the global economy. The prospects for strengthening the competitiveness of Ukraine's economy evaluating based on the modified approach for assessing the revealed comparative advantage. The dynamics and structure of major industries exports were estimating. The research result proved that the growth of innovative products in the iron and steel industry increases its competitiveness in the world market. The established reduction of the identified comparative advantages index for the main exports positions reflects the presence of structural and technological lags in the modern structure of the national economy and requires economic policy measures aimed at long-term action. Respectively, the main goals of contemporary national economic policy aimed at promoting the export competitiveness of Ukrainian products (goods \& services) have to be the stimulating of R\&D, infrastructure modernization and capital deepening.
\end{abstract}

\section{Introduction}

2020 marked the beginning of the global recession in global economic dynamics. This recession was quite expected due to the long period of previous growth, the accumulation of global imbalances, especially in the financial markets. Nowadays the forecasts of the future global situation in the context of the stability of existing national economic models, the capabilities of regional integration associations, the capacity and capacity of international organizations, their ability to effectively address external and internal challenges intensified. The cyclical nature of economic development objectively determines the change in the tools of state regulation for ensuring its stability. The challenges of the COVID-19 pandemic and the resulting large-scale economic constraints have significantly changed the target priorities of national and international economic policy $[1,2]$. The dilemma of the priority of state support faced the countries of the European Union, is also the characteristic for the individual states' economic policy. The issue of choice in the EU was the focus of economic policy on reducing interstate socio-economic differentiation and the commitment of individual countries (for example, Poland and Hungary), using the temporary concentration of power at the national government level, to move away from EU fundamental values, including protection freedom, equality, rule of law. The approach of opponents of a common European anti-crisis policy

\footnotetext{
*e-mail: 1_petkova@ukr.net

**e-mail: o.berezina@chdtu.edu.ua

***e-mail: irynahoncharenko@gmail.com

****e-mail: meb@chdtu.edu.ua
}

leads, among other consequences, to non-transparent and economically unjustified support for near the government businesses through financial incentives.

Activation of competitive advantages of the national economy is determined by the available human, physical, natural potential, level and complementarity of economic development due to the basic theory of M. Porter [3]. H. Davies and P. Ellis [4] determined productivity of industries as the more important factor for country's sustainable economic growth. The effective means of strengthening the national economy in the era of domination of multinational companies is the ability to adjust the production of national firms and industries within global value chains, according to AJ Smith (2010) [5], S. Chopra and P. Meindl [6], J. A. Robinson and D. Acemoglu [7] noted that the basic issue of ensuring the preconditions for sustainable economic growth, strengthening international competitiveness and improving the quality of life in growing countries is the creation of inclusive economic and political institutions. The functioning of these institutions determines the possibility of progress in education and technology - factors that increase the productivity of the economy, industries and enterprises.

The most significant factors in increasing production productivity and competitiveness at the current stage of post-industrial development are the conditions for improving key economic factors - human capital and technology. The relationship between the quality of human capital and technology, the ability of employees to use new technologies and to improve them were studied by J. R. Baldwin, B. Diverty and D. Sabourin [8]. They grounded, that productivity of human capital is significantly higher in indus- 
tries where modern information and communication technologies are used. Widespread use of these technologies leads to cost reductions, changes in business organizational structures. Wages growth faster in industries that actively use modern technology. Moreover, firms that support the training of their employees and carry out research and development are more technological and competitive.

Infrastructure factors are effective for the constant increase in capital and labour productivity. Analysis of public investment in infrastructure projects reflects the importance of their effective management, especially in emerging markets, to mitigate the threat of budget imbalances. A. Isaksson noted [9] that the basic preconditions for increasing productivity and competitiveness are investments in human capital (education and health care), improvement of infrastructure, financial security, and development of basic institutions (openness and competition). Good governance is the key to the success of quality, productivity and competitiveness policies.

The case analysis of some countries with growing markets made by B. F. Filip [10] proves the priority of information technology, increasing the share of R\&D in total costs for increasing multifactor productivity and growth of competitiveness.

The interaction and role of social, human and technological capital in increasing TFP were studied by B. Dettori, E. Marrocu and R. Paci [11]. The results of their study confirm the high effectiveness of these factors supporting policy for providing productivity growth, economic cohesion in European regions. Simultaneous support and interaction of technological, human and social capital form the spatial poles of accelerated development.

The role of international trade in national competitiveness has been studied by G. Muratoğlu and Y. Muratoğlu [12]. They determined the determinants of export competitiveness and grounded that transnational FDI has not always made a positive impact on national productivity. Instead, the growth of the share of high-tech export has a clear positive effect on the growth of the country's comparative advantages.

The challenges of increasing national economic productivity are quite acute for Ukraine. Decades of transformational development have not formed a consistent trend of improving the quality of economic growth factors and long-term prerequisites for productivity gains. One of the main challenges for Ukraine is the creation of new competitive advantages associated with investments in the latest technologies, innovations, research, human capital, efficient allocation of resources and redistribution, which is accompanied by changes in the behaviour of economic entities [13].

Respectively, the main goals of contemporary national economic policy aimed at promoting the export competitiveness of Ukrainian products (goods \& services) have to be the stimulating of $\mathrm{R} \& \mathrm{D}$, infrastructure modernization and capital deepening.

In this issue the method for assessing the revealed comparative advantage used for estimating the prospects for strengthening the competitiveness of Ukraine's economy through the dynamics and structure of exports of ma- jor industries. The modified approach to the assessment of comparative advantages is based on the method of determining the coefficient of the revealed comparative advantage (Revealed Comparative Advantage, RCA) [14].

$$
R C A=\frac{1000}{X_{j}^{t}+M_{j}^{t}} \times\left[X_{i j}^{t}+M_{i j}^{t}-\left(X_{j}^{t}-M_{j}^{t}\right) \times \frac{X_{i j}^{t}+M_{i j}^{t}}{X_{j}^{t}+M_{j}^{t}}\right]
$$

where $X_{j}^{t}$ - the total exports of the country $(s)$ relatively to the group of other analyzed countries;

$M_{j}^{t}$ - the total imports of the country (i) relatively to the group of other analyzed countries;

$X_{i j}^{t}$ - the export of the industry or sector $(j)$ of the country (s) relatively to the group of other analyzed countries;

$M_{i j}^{t}$ - imports of goods of the sector $(j)$ of the country (i) relatively to the group of other analyzed countries.

This work aims to analyze the prospects for the competitiveness of Ukrainian exports in the terms of pandemic circumstances and post-pandemic recovery of the global economy.

\section{Results}

The GDP of most countries reduced in 2020. According to IMF[15] estimates, the economic decline is expected at the global level (world) $-4.4 \%$, in the group of developed countries (advanced economies, $\mathrm{AE}$ ) $-5.8 \%$, in growing and developing countries (emerging markets and developing economies, EMDE) $-3.3 \%$. The expected decline in Ukraine's GDP in 2020 is $7.2 \%$ [15]. Overcoming the effects of the global economic crisis is difficult for advanced economies, but low-income countries (LIC) are particularly affected and burdened with significant external debts. About 1.5 billion people in the least developed countries feel the weakness of national health care systems and institutional failure. The total amount of state-to-business support for employees was about $20 \%$ of GDP in AE during the quarantine period. However, in LIC this support was only about $2 \%$ of GDP. It has to be noted that national governments implement active measures to minimize the effects of the crisis and pandemic. As in previous situations of global economic downturn, monetary easing measures are being taken, and businesses are receiving significant fiscal and credit support to minimize losses from the recession.

The EU's response to the latest threats is significant. It reflects a clear awareness of partnership and solidarity advantages in overcoming challenges, as well as strengths of collective and coordinated action in contrast to individual decisions. The European Commission is implementing the Coronavirus Response Investment Initiative (CRII) to mobilize cohesion policy and for speed response to threats[16]. The main objectives of European policy against the pandemic and economic downturn are the support for health systems, labour markets, small and medium-sized businesses and help the most affected regions. The list of national business support measures introduced by European countries can be divided into the fol- 
lowing areas: tax incentives (deferral and reduction of tax payments), financial guarantees for companies that need the additional resources during the crisis, simplification of credit support, income support, subsidies for wages in forced part-time employment, etc. [17]. The example of $\mathrm{AE}$ and integration associations makes it possible to adjust the economic policy of other countries in a pandemic and economic recession.

Ukraine's economy is declining in key macroeconomic indicators. The decline in some of them was recorded before the global pandemic and significantly deepened by its effects. For example, the index of industrial production began the ongoing decline in October 2019, the turnover of transport companies began the ongoing decline in January 2020. The set of preconditions determines the complexity of this situation, both internal and external, and economic recovery requires an active public policy using the most effective and proven measures.

The dynamics of the Ukrainian economy competitiveness through the RCA index for the largest export goods and services categories during last seven years given in table 1 .

Iron and steel were the largest export category of Ukraine until recently. Ukraine sold more grain crops than iron and steel at the total cost only in 2019. The main importers of Ukrainian steel are Italy, Egypt, Russia, Turkey and Poland. Products of this category are mainly raw materials. The index of Ukrainian iron and steel exports tends to decline steadily, which indicates a deterioration in the competitiveness of domestic metallurgy. For example, in 2013 the value of the indicator was 97.66, but in 2019 it was only 76.25 , and further deterioration and decline expected. Iron or steel products are other types of metallurgical products that have a significant decrease in the index also. In 2013 it was 12.5 , but in 2019 - only 1.35 . Insufficient level of technological renewal of Ukrainian metallurgy against the background of increasing competition in the industry and aggressive policy of competitors to expand markets create a negative outlook for domestic exports.

Instead, exports and the competitiveness of the Ukrainian agricultural sector are growing. Indices of the categories "cereals", "seeds and fruits of oilseeds", "animal and vegetable fats", "residues and wastes of the food industry" are growing. RCA indicators doubled for each category. However, due to the lower level of the agricultural sector adaptability, its role in the structure of export specialization hasn't to be prevailing.

Ukraine has negative RCA indices for electric machines, nuclear reactors, boilers and machines - categories where imports are more than exports. At the same time, the dynamics indicate that the competitiveness of electric machines has halved in the last six years, and of nuclear reactors, boilers and machines - three times. The index of wood and wood products has almost doubled. The main product is lumber - the raw materials for the manufacture of furniture et al. Thus, the manufacturability of Ukrainian commodity exports and competitiveness of more technological categories of exports and industries has decreased over the past seven years.
The indicators of the RCA index for the largest categories of Ukrainian exports of services shown in table 2.

The situation with the competitiveness of Ukrainian services is much more optimistic than with goods. The trade balance of transportation, namely: sea, air, rail, road and pipeline services is positive. Ukraine is using its potential as a transit state. The pipeline transport services amount half of all transport services exports. The index of transport services competitiveness is volatile and hasn't an obvious tendency to increase or decrease.

The competitiveness of computer and information services tripled and the competitiveness of telecommunications services increased more than doubling. The main trade partners in computer, information and telecommunications services are the United States, the United Kingdom, Israel, Malta and Germany. Half of the services in this area are exported to the United States. IT sector is one of the most promising areas of further development and specialization with significant potential for value-added. Moreover, during this period, the competitiveness of construction, financial, insurance and other types of services has increased. Ukraine changed its status from an importer to an exporter in construction services, the index has increased 8 times. For financial services, this indicator doubled.

Ukraine's position in 2019 improved by 5 points in the Doing Business Ranking (71st of 190 countries). The country showed the largest growth in such categories as taxation (growth by 110 positions, 54th place), international trade (+70 positions, 78th place) and investor protection (+56 positions, 72nd place). In the Doing Business 2020 (DB 2020), Ukraine hold 64th place, improving its position compared to Doing Business-2019, by seven points [20]. The greatest progress was in the indicators "protection of minority shareholders" (the position improved by 27 points), and "obtaining the permissions for building and construction" by 10 points.

Meanwhile, the rating agency Moody's Investors Service upgraded Ukraine's sovereign rating from $\mathrm{Caa} 2$ to Caa1, which means a change in the prognosis from "positive" to "stable".

Ukraine ranked 83rd out of 140 in the Global Competitiveness Index (GCI 2020 Ukraine ranks 110th in terms of state institutions, 57 th in terms of infrastructure development, 77th in terms of adaptation of modern technologies, as well as macroeconomic stability - 131st, healthcare 94th, education - 46th place, goods market - 73rd, labour market - 66th, financial system -117 th, market size 47 th, business dynamics -86 th, ability to innovate -58 th) [21].

In the Global Innovation Index 2020 [22], Ukraine rose 7 places to 43rd, ahead of Thailand and behind Croatia and Greece. At the same time, Poland took 39th place, Russia - 46th, Moldova - 48th, Kazakhstan - 74th, Belarus -86 th. The best indicator in the group of the former USSR obtained by Estonia which took 24th place. The leaders of the ranking are the following ten most innovative countries: Switzerland, the Netherlands, Sweden, Great Britain, Singapore, the United States, Finland, Denmark, Germany and Ireland. 
Table 1. Index of Ukrainian goods exports competitiveness (according to the data $[18,19]$ )

\begin{tabular}{|c|c|c|c|c|c|c|c|}
\hline \multirow{2}{*}{ Categories } & \multicolumn{7}{|c|}{ Years } \\
\hline & 2013 & 2014 & 2015 & 2016 & 2017 & 2018 & 2019 \\
\hline Iron and steel & 97.66 & 107.78 & 96.78 & 89.35 & 88.30 & 91.58 & 76.25 \\
\hline Cereal crops & 47.87 & 57.33 & 77.37 & 81.51 & 73.01 & 73.77 & 93.85 \\
\hline Animal and vegetable fats & 24.84 & 32.68 & 40.84 & 51.29 & 50.30 & 44.83 & 44.76 \\
\hline Ore, slag, ash & 25.83 & 26.08 & 21.31 & 21.14 & 25.90 & 27.10 & 31.23 \\
\hline Electric machines & -11.27 & -10.11 & -9.96 & -12.23 & -12.07 & -17.27 & -26.76 \\
\hline & 13.51 & 12.79 & 16.48 & 17.01 & 20.10 & 17.51 & 22.10 \\
\hline Reactor & -14.42 & -17.53 & -21.96 & -38.17 & -38.08 & -38.50 & -37.51 \\
\hline Wood and products of wood & 6.39 & 9.12 & 12.65 & 13.14 & 11.43 & 13.17 & 11.41 \\
\hline Residues and waste from the food industry & 5.38 & 8.06 & 10.95 & 11.57 & 10.41 & 10.70 & 12.82 \\
\hline Steel or iron products & 12.50 & 7.97 & 5.07 & 1.24 & 2.22 & 3.14 & 1.35 \\
\hline
\end{tabular}

Table 2. Index of Ukrainian services export competitiveness (according to the data $[18,19])$ )

\begin{tabular}{lccccccc}
\hline \multirow{2}{*}{ Categories } & \multicolumn{7}{c}{ Years } \\
\cline { 2 - 8 } & 2013 & 2014 & 2015 & 2016 & 2017 & 2018 & 2019 \\
\hline Transportation & 152.10 & 143.85 & 153,21 & 160.01 & 145.73 & 123.37 & 151.94 \\
Computer and information services & 13.16 & 30.32 & 35.80 & 41.05 & 42.00 & 50.68 & 38.19 \\
Business services & -20.03 & -21.75 & -21.40 & -33.06 & -29.19 & -58.70 & -49.92 \\
Tourism & -29.45 & -39.93 & -40.45 & -42.10 & -54.84 & -59.86 & -73.72 \\
Communication services & -8.11 & -0.47 & -6.44 & -1.13 & -3.09 & -1.96 & -3.03 \\
Construction services & -8.64 & -1.42 & 10.47 & 12.71 & -4.45 & 1.68 & 0.41 \\
Financial services & -49.99 & -48.75 & -64.10 & -44.13 & -31.60 & -30.26 & -26.16 \\
Insurance services & -7.30 & -4.27 & -4.00 & -7.69 & -8.84 & -3.90 & -3.53 \\
Fees for royalty and licenses & -47.38 & -28.54 & -22.80 & -26.27 & -31.99 & -33.96 & -33.59 \\
Personal, cultural and health services & -0.91 & 0.52 & 0.06 & -0.07 & -1.07 & -0.11 & -0.09 \\
\hline
\end{tabular}

The basis of Ukrainian innovative competitiveness is human capital and research, as well as knowledge and research results. Their effective implementation is the main competitive advantage. However, compared to 2017, Ukraine lost 2 positions in the sub-index "Human Capital and Research", decreasing from 41st to 43rd place due to a reduction in education costs as a percentage of GDP and research and development costs as a percentage of GDP. At the same time, in the sub-index "Knowledge and results of scientific research", Ukraine is in a high 27th place in the overall ranking. The main strengths of this sub-index are the following: knowledge creation (15th place), the ratio of patents to GDP at purchasing power parity (19th place), the ratio of utility models to GDP at purchasing power parity (1st place), the cost of computer software as a percentage of GDP (17th place), exports of ICT services as a percentage of total trade (15th place).

In the Bloomberg Index of Innovative Development (BIID 2019) Ukraine obtained the 53rd place in 2019 with a total score of 48.09 , deteriorating its position by a total of 7, due to the weakening of Ukraine's position on 6 of the seven components of this index (table 3), authors' calculations according to the data [23].

According to the latest published report of the World Economic Forum "The Global Competitiveness Report 2019" [21], Ukraine ranked 83rd among 140 countries. The Dominican Republic is in the 82nd place, and Macedonia is in the 84th place. Compared to the data of the previous report, Ukraine lost 2 positions, but such a compari-
Table 3. Ukraine's position in the Bloomberg Innovation Index

\begin{tabular}{lcc}
\hline \multirow{2}{*}{ Index } & \multicolumn{2}{c}{ Years } \\
\cline { 2 - 3 } & 2018 & 2019 \\
\hline General index & 46 & 53 \\
$\begin{array}{l}\text { Intensity of research and development } \\
\text { (R\&D expenditures / GDP) }\end{array}$ & 54 \\
$\begin{array}{l}\text { Productivity } \\
\begin{array}{l}\text { Penetration of high technologies (share } \\
\text { of innovative companies in the total }\end{array}\end{array}$ & 52 & 60 \\
$\begin{array}{l}\text { number of enterprises) } \\
\begin{array}{l}\text { Concentration of researchers (number of } \\
\text { scientists per 1 million inhabitants) }\end{array}\end{array}$ & 46 \\
$\begin{array}{l}\text { Value added production (value added of } \\
\text { production / GDP) }\end{array}$ & 48 & 58 \\
$\begin{array}{l}\text { Efficiency of higher education (share of } \\
\text { freelance graduates in the total number } \\
\text { of graduates of educational institutions) }\end{array}$ & 21 & 28 \\
\begin{tabular}{l} 
Patent activity \\
\hline
\end{tabular} & 27 & 35 \\
\hline
\end{tabular}

son is incorrect, as the report for 2018 changed the method of calculating the index and its components. According to the new approach, the ranking is led by the United States, Singapore and Germany. Yemen and Chad have the lowest level of competitiveness - 139th and 140th respectively. Ukraine's geographical neighbours have the best positions: Poland - 37th place, Slovakia - 41st, the Russian Federation - 43rd, Hungary - 48th, Romania - 52nd. The authors of the rating (GCR 2019) noted that Ukraine 
occupies a fairly high position in the sub-indices: market size -47 th place, skills -46 th place. Instead, the most problematic are the sub-indices macroeconomic stability (131st), the financial system (117th), institutions (110th).

In the report "European Innovation Scoreboard 2019" [24], the leader in innovation is Sweden. The leader's group also includes Denmark, Finland, Germany and the Netherlands. Ukraine's position has decreased, and now its level corresponds to the group of European innovation outsiders (Romania, Bulgaria). The value of the aggregate index for Ukraine in 2019 was $27.8 \%$ (in 2016 - 28.9\%), which indicates a decline of $1.1 \%$ compared to 2016 . According to the methodology, Ukraine is in the group of slow innovators. Ukraine lags behind in all indicators, except for human resources $(110.3 \%)$ and the impact of employment $(77.5 \%)$. The weakest sides are communications and entrepreneurship (9.5\%), the innovation environment (4.1\% in 2017, no data in 2010 and 2016). According to the report, Ukraine is characterized by a low level of GDP per capita in 2017 - 6,600 USD (by PPP), while the average value of this indicator in the EU is 28,600 dollars. Ukraine's GDP growth rate and population growth rate are negative.

The export of goods consists of about $80 \%$ in the general structure of Ukraine's exports, and the strategic goal of increasing its manufacturability is important to strengthen the key characteristics of competitiveness in foreign markets. The production of iron and steel industry is stable at $20-25 \%$ of the total volume of industrial production in Ukraine during 2001-2019 years. The results of the calculating relationship between the share (percent) of innovative industrial products $(x)$ in iron and steel industry, and the Ukrainian iron and steel industry competitiveness (y) shown in table 4.

Table 4. The share of innovative products and competitiveness of iron and steel industry (according to the [18] data)

\begin{tabular}{ccc}
\hline Year & $x$ & $y$ \\
\hline 2000 & 9.4 & 163.67 \\
2001 & 6.8 & 144.16 \\
2002 & 7.0 & 140.11 \\
2003 & 5.6 & 134.86 \\
2004 & 5.8 & 150.20 \\
2005 & 6.5 & 151.24 \\
2006 & 6.7 & 152.79 \\
2007 & 6.7 & 149.64 \\
2008 & 5.9 & 149.88 \\
2009 & 4.8 & 116.29 \\
2010 & 3.8 & 125.51 \\
2011 & 3.8 & 117.14 \\
2012 & 3.3 & 96.93 \\
2013 & 3.3 & 97.66 \\
2014 & 2.5 & 107.78 \\
2015 & 1.4 & 96.78 \\
2016 & 1.0 & 89.35 \\
2017 & 0.7 & 88.30 \\
2018 & 0.8 & 91.58 \\
2019 & 1.3 & 76.25 \\
\hline
\end{tabular}

The research result proved that the growth of innovative products in the iron and steel industry increases its competitiveness in the world market. The values of the calculated parameters of the linear function are presented in the linear regression equation (2).

$$
Y=77.55618-10.2068 x
$$

The linear correlation coefficient for this model is 0.95 . The coefficient of determination shows that the competitiveness of iron and steel industry products $(y)$ by $89.35 \%$ depends on the share of innovative industrial products $(x)$, and $10.65 \%$ is the influence of other factors. Thus, the increase in the share of innovative products in the exports of the Ukrainian iron and steel industry is the determining factor in its competitiveness on the world market. From 2013 to 2019, the level of manufacturability of Ukrainian merchandise exports and its competitiveness decreased, while the competitiveness of Ukrainian services, primarily IT, as well as financial and insurance services increased. The position of Ukrainian producers in global value chains remains unfavourable due to the export of low value-added products and imports of high-tech goods.

The level of state participation and regulation of economic and private sphere is another nowadays topical issue. According to Y. N. Harari [25], humanity is faced with two particularly important choices between totalitarian surveillance and the support and information of citizens; between nationalist isolation and world solidarity during the crisis. The experience of countries that slowed down the spread of the epidemic is essential. Some countries use the geolocation data actively for tracking the movement of sick persons or population at risk. In China, Taiwan, Singapore, South Korea, Israel, various technical solutions are used to monitor people, their movement and contacts. The so-called "digital strategy of human identification" is used by European countries for the period of the pandemic. Such decisions are not easy for democratic countries, because the threat to civil liberties is quite real and conscious in the current circumstances. Therefore, their governmental and interstate policies are aimed at combining the necessary restrictive measures and protection of confidentiality as much as possible. However, in autocratic states, there is no public discussion about the expediency of using additional tools for state control of private life. It is possible to assume a significant transformation of political models in some countries based on assessing the prospects of the post-crisis period of global development. However, the existing political tradition, maturity and responsibility of political elites and civil society for the implementation of priority worldview values will remain decisive.

\section{Conclusions and suggestions}

The global economy today faces serious and numerous challenges. Methods for overcoming the traditional problems of the cyclical downturn are complemented by the daily experience of overcoming the COVID-19 pandemic. The challenges for government anti-crisis policy in EMDE 
are reinforced by the need to establish long-term trends in sustainable economic growth.

The countries represented on the world market by transnational companies are gaining more and more competitive advantages in the international division of labour with the strengthening of global interdependence. Digital technology-based businesses have significantly improved their competitive position in terms of the pandemic. Namely, e-commerce has almost tripled during this time. The significant funding for the formation of a longterm national strategy for post-pandemic growth is the emphasis on high-tech and digital businesses.

Ukraine's economy has a high level of integration into world markets. At the same time, it has loses because of the efficiency and manufacturability of foreign economic activity. The established reduction of the identified comparative advantages index for the main branches of goods' exports reflects the presence of structural and technological lags in the modern economic structure of the country and requires economic policy measures aimed at long-term action. Instead, the Ukrainian economy demonstrates positive dynamics in the export of services and reflects the progressive trends of technological development, first of all in the export of IT services. Analysis of the Index of Ukrainian goods exports competitiveness, Index of Ukrainian services export competitiveness reflects a steady trend towards the loss of long-term competitiveness of Ukrainian industries for the production of goods, especially raw materials. At the same time, there is a positive trend to expand the competitive capabilities of modern high-tech services - Computer and information services, Communication, Construction services. Sustain the conditions for further foreign economic expansion of these Ukrainian businesses is one of the main tasks for the government's economic policy.

Governments are taking emergency measures to address global economic challenges and support national economies. The scale of financial support for citizens during the period of temporary loss of their solvency and business unprecedented, especially for small and medium businesses. The considering the growing global challenges including the COVID-19 pandemic, returning the crucial role of economic policy to national governments, also increasing the international coordination of crisis efforts and shifting the emphasis to stimulating economic activity of small and medium businesses would shape the economy policy shortly. The maximally support the abovementioned high-tech businesses-locomotives of long-term growth and using of such experience is significantly important for Ukraine. Primarily, fiscal and monetary stimulus measures will be appropriate.

Despite the need for additional protection of national economies and, consequently, change of the existing practice of international integration, the objective reasons for its renewal will not disappear in the post-crisis period. The commonality of the current epidemiological, economic, and social challenges also determines the joint efforts to overcome them. The world economy will change as with any crisis, but with a new experience in countering global threats, the number of which isn't decreasing.
Ukraine's foreign economic policy has to be based on the possibility of effective integration into world value chains, logistics and communication networks due to the further consolidation of international efforts to solve global problems.

Further research will be devoted to elaborating the specific mechanisms to increase the manufacturability and competitiveness of both traditional and new industries of Ukrainian exports.

\section{References}

[1] S. Semerikov, S. Chukharev, S. Sakhno, A. Striuk, V. Osadchyi, V. Solovieva, T. Vakaliuk, P. Nechypurenko, O. Bondarenko, H. Danylchuk, E3S Web of Conferences 166 (2020)

[2] V.N. Soloviev, A.O. Bielinskyi, N.A. Kharadzjan, CEUR Workshop Proceedings 2832, 24 (2020)

[3] M.E. Porter, Competitive advantage of nations: creating and sustaining superior performance (Simon and Schuster, 2011)

[4] H. Davies, P. Ellis, Journal of Management Studies 37, 1189 (2000)

[5] A. Smith, Southern African Business Review 14 (2010)

[6] S. Chopra, P. Meindl, Supply chain management: strategy, planning, and operation (2001), https://base-logistique-services.com/ storage/app/media/Chopra_Meindl_SCM.pdf

[7] J.A. Robinson, D. Acemoglu, Why nations fail: The origins of power, prosperity and poverty (Profile, London, 2012)

[8] J.R. Baldwin, B. Diverty, D. Sabourin, Technology use and industrial transformation: Empirical perspective (1995), http://citeseerx.ist. psu.edu/viewdoc/download?doi=10.1.1.622. $1001 \&$ rep=rep $1 \&$ type $=$ pdf

[9] A. Isaksson, Determinants of total factor productivity: a literature review (2007), https: //open . unido.org/api/documents/4812034/ download/UNIDO-Publication-2007-4812034

[10] B.F. Filip, Journal of Public Administration, Finance and Law 10, 125 (2016)

[11] B. Dettori, E. Marrocu, R. Paci, Regional Studies 46, 1401 (2012)

[12] G. Muratoğlu, Y. Muratoğlu, Journal of Economics and Political Economy 3, 111 (2016)

[13] L. Petkova, O. Berezina, I. Honcharenko, L. Berezhna, D. Marushchak, E3S Web of Conferences 166, 13014 (2020)

[14] S.R. Semiv, Research of competitiveness of branches of Ukraine economy in the conditions of European integration (2007), http://mev. lac.lviv.ua/downloads/vyklad/ semiv/stattya_competitiveness.pdf

[15] International Monetary Fund, World Economic Outlook, October 2020: A Long and Difficult Ascent (2020), https://www.imf.org/en/ 
Publications/WEO/Issues/2020/09/30/ world-economic-outlook-october- 2020

[16] European Comission, Cohesion policy action against coronavirus (2020), https: //ec.europa.eu/regional_policy/en/ newsroom/coronavirus-response/

[17] A brief overview of corona-related national and regional policy measures taken to support SMEs (2020), https://drive.google.com/file/d/ 13dJFoeyu0CMA6FPAnnfxM1n5rmvRSSqo/view? fbclid=IwAR3GrAy6u7np6HQ_iQdOHDI

[18] Ukrstat, Official site of the State Statistics Service of Ukraine (2020), http: //www . ukrstat.gov .ua/

[19] United Nations, UN Comtrade Database (2020), https: //comtrade.un.org/

[20] World Bank Group, Doing Business 2020: Comparing Business Regulation in 190 Economies (2020), https://tinyurl.com/3uh5bnjm

[21] K. Schwab, ed., The Global Competitiveness Report 2019 (World Economic Forum, Cologny/Geneva, 2019), http://www3.weforum.org/docs/WEF_ TheGlobalCompetitivenessReport2019.pdf

[22] Global innovation index 2020 (2020), https:// www.globalinnovationindex.org/

[23] P. Coy, Bloomberg Index of Innovative Development (2015), https://www.bloomberg.com/ graphics/2015-innovative-countries/

[24] Official site EU Commission (2021), http://ec. europa.eu

[25] Y.N. Harari, The world after coronavirus (2020), https://www.ft.com/content/ 19d90308-6858-11ea-a3c9-1fe6fedcca75 